\title{
Ethnobiology and Indigenous Knowledge about Medicinal Animals and Plants in the Balami Ethnic Group in Nepal
}

\author{
S.H. Timilsina ${ }^{1}$ and N.B. Singh ${ }^{2}$ \\ Central Department of Zoology, T.U., Kirtipur, Kathmandu, Nepal. \\ ${ }^{1}$ E-mail: shreehari.timilsina@gmail.com \\ ${ }^{2}$ E-mail:nanda_nepal@yahoo.com
}

\begin{abstract}
The main purpose of the study was to document the medicinal animals and plants used by the unique ethnic group; 'Balami', native of Okharpauwa VDC of Nuwakot district. The information was collected in the area using an integrated approach of zoological and botanical collections, group discussions, interviews and questionnaires. It enumerates an account of ethnography with the list of 65 animal species belonging to 31 orders, 46 families and 62 genera. Out of which 55 species are wild and 10 species are domesticated. The Balami utilize these animals mainly for food, medicine, companion, ceremony, agriculture etc. They use 15 species of animals for medicinal purpose among which 13 are wild and 2 are domesticated to cure 16 different types of diseases. Balami have brought altogether 185 different plant species into use. Among them 80 species are brought from the local forest, 87 species are cultivated and 18 species of the plants are purchased from the nearest market. These plant species are included under 65 families and 151 genera. They use 45 different plant species to cure 55 different diseases out of which 32 are wild, 12 are cultivated and 1 is purchased from the remote area. The present inventory will play a catalytic role for implementation of development programs in the region, recommendations of the conservation and sustainable use based on indigenous knowledge from the elder to the younger generations.
\end{abstract}

Keywords: Ethnobiology, indigenous knowledge, traditional medicine, medicinal animals and plants, Balami.

\section{INTRODUCTION}

Dynamic and intimate relationships have been established between human, plants and animals. Human being has been always inspired about the uses of various plants and animals species. As a result, they used different vegetational resourses, animal and animal extracts for manifold purposes like food, medicine, fibre etc. Generally, ethnobiology is a decipline of recording knowledge of indigenous people about uses of animals and plants inheritetd through generations. It has multidisciplinary endevour that contributes to explore how local people interact with plant and animal resources. Ethno-medicine consists of those beliefs and practices relating to diseases which are products of indigenous cultural development and are not explicitly derived from the conceptual framework of the modern medicine (Mishra et. al. 2006). Ethno-medicinal practices and beliefs are moulded in the nooks and corners of the world even after the revolution brought by the modern medicine. It is because of the relationship of the local people with the elaborate patient healers, low cost and cultural acceptability.

Traditional medicines are still the only defense for the poor people living in remote areas far from modern health care facilities. However, documentation and analysis of such knowledge is lagging and in verge of extinction. Thus, it is our responsibility to preserve indigenous knowledge system for providing affordable and sustainable health care. Balami are among the least known of Nepal's indigenous people. Apart from the ancient agricultural activity, they were traditionally woodcutters and firewood sellers living near forested areas all around the ridge encircling the Kathmandu valley. Most of them have given up traditional woodcutting activity, as there is no adequate firewood to satisfy the need of Kathmandu valley. Porterage was formerly another major occupation of this group. They used to carry goods along the Bhimphedi-Kathmandu track, along the old footpath from the Kathmandu valley to India where all transportation is still ensured by porters (Toffin, 2007). They are good field workers and buffalo traders. They are the mediators between civilized world of villages and towns undergoing socialization and acculturation. In these circumstances this indigenous group is waning in Nepal. This research work is an effort to document such indigenous knowledge in Balami, a minor group under Newar ethnic community. Thus, the main objective of this study was to document ethnobiology, ethnomedicine and preserve indigenous knowledge system of Balami.

\section{MATERIALS AND METHODS}

\section{Study area}

Okharpauwa VDC is the study area which lies in the Nuwakot district of Bagmati zone. It is one of the underdeveloped VDC out of 62 VDCs of Nuwakot 
district (CBS, 2012). It is located in between the latitude $27^{\circ} 46^{\prime} 32.59^{\prime \prime} \mathrm{N}$ to $27^{\circ} 48^{\prime} 11.00^{\prime \prime}$ North and longitude $85^{\circ} 14^{\prime} 46.32^{\prime \prime} \mathrm{E}$ to $85^{\circ} 17^{\prime} 52.69^{\prime \prime}$ East and within an elevation range from $1200 \mathrm{~m}$ to $1900 \mathrm{~m}$ from the sea level. The village entirely lies in Kolpu Khola watershed, which is north western part of Kathmandu. In its east, Jitpur Fedi VDC of Kathmandu, west, Chauthe VDC of Nuwakot, north, Kakani VDC of Nuwakot and south, Deurali VDC of Dhading distrits are located. The area is rather sloppy. Like the general hilly area, Brahamin, Chhetri, Tamang, Balami, Newar, Damai, Kami etc., live here. They all have their own language and religion.

From north to south, the study area is underlain by Himalayan gneiss group composed of various gneisses forming the Kakani-Shivapuri ridge; Tibetan sediments composed of quartzite, phyllite, siltstone, sandstone and schists in the centre and marble in the south (Caine \& Mool, 1982). The climate of Okherpauwa varies from subtropical sub-humid in the river valleys to warm temperate humid in the upper ridges and mountain tops. The maximum and minimum temperatures vary from 22.1 to $11.4^{\circ} \mathrm{C}$ in summer and 13.5 to $1.1^{\circ} \mathrm{C}$ in winter. More than $80 \%$ of the annual precipitation is received during the rainy season which normally occurs between Mid Junes through late September.

Okherpauwa supports subtropical vegetation consisting of Schima wallichii (chilaune) and Castanopsis indica (Katus). The middle slopes of the mountains have Pinus roxburghii (Sallo), Quercus lanata (Banjha) and Rhododendron spp (Laligurus). Alnus nepalansis (Uttis) occupies almost all wet ravines and gullies. Eupatorium sp. (Banmara) occurs extensively in degraded forest and scrubland. Some trees of Toona ciliate (Tuni), Dalbergia sisso (Sisau), Albizia lebbeck (siris) are also found. Among mammalian fauna Canis aureus (Jackal), Panthera pardus (Chituwa), Macaca mulata (Bandar) etc., are found.

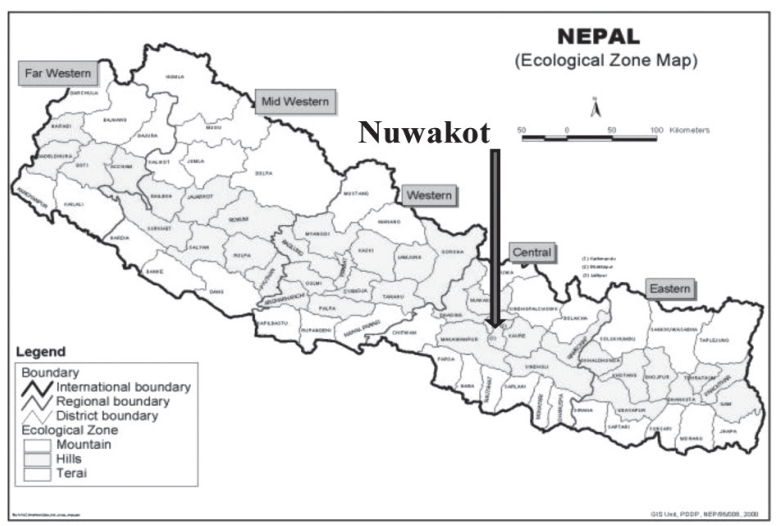

Fig. 1: Map of Nepal

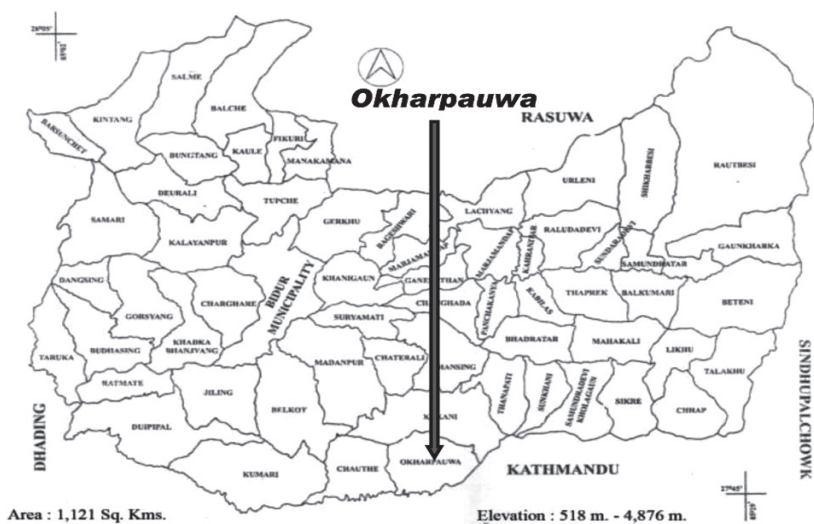

Fig. 2. Map of Nuwakot District

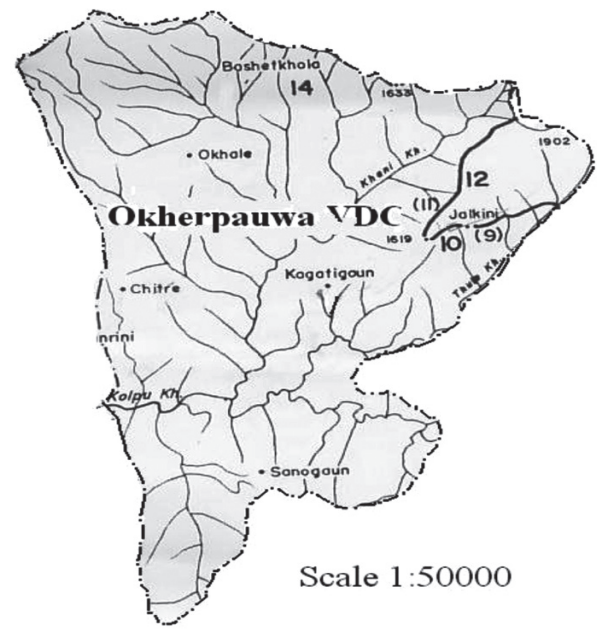

Fig. 3. Map of Okharpauwa VDC

To undertake this research, ethnomedicinal data as primary data were collected from the study area through observation, participation and interviews. A standard set of questionnaires were used in order to obtain the detail information about the medicinal plants and animals. Informal interviews were taken with reliable persons and the local people such as old persons and traditional faith healers. Photo collection was made. Four major field visits of five days each during 2007 and 2008 and many informal field visits were made there after. Random sampling techniques were employed to recruit 29 interwiew subjects. The actual condition of ethnobiology and indigenous knowledge about medicinal animals and plants were observed directly and recorded from the key informants and faith healers. The plant specimens were collected and identified on the spot with the help of the local people and some were identified with the help of botanists and zoologists from the Central Department of Zoology and Botany (T.U.) respectively and the National 
Herbarium, Godawari, Kathmandu. Various tables were made for the identification, classification and medicinal uses. Similarly, the secondary data were used for the study, which were collected from experts, organizations, national and international journals, publications and text books.

\section{RESULTS}

Balami from time immemorial were relying on the forest and the forest prodcucts. Later on they changed themselves as good field workers. They utilized a wide variety of plant and animal species. They have keen love to the animals they domesticate and the forest products. They are more cultural in the protection of the forest. The study of ethnozoology of Balami reveals that 65 different kinds of animals both vertebrates and invertebrates. The vertevrates numbering 51 species include mammals, aves, reptiles, amphibians and fishes whereas, the invertebrata include 14 species, together with annelids, crustaceans and molluscs. The vertebrata belongs to 21 orders, 34 families, 49 genus and 51 species whereas the invertebrata include 10 orders, 12 families 13 genus and 14 species. Thus, the total faunal resources of ethnobiological significance to Balami encompass 31 orders, 46 families, 62 genuses and 65 species among them 55 species are wild and 10 species are domesticated. They utilize these animals mainly as food and medicinal purposes. Some of the animals are used as companion, ceremonial, agricultural etc.
Balami have brought altogether 185 different plant species into use. Among them 80 species are brought from the local forest, 87 species are cultivated and 18 specie are Purchased from the nearest market. These plant species are included under 65 families and 151 genera. Among 185 species, Mycophyta consists of 1 family, 1 genus and two species. Both of them are wild. Pteridophyta consists of 3 families, 3 genus and 3 species. All the 3 species are wild. Gymnosperms are included under 2 families, 2 genera and 2 species. These are also wild. Monocots are included under 12 families, 33 genera and 35 species. Among them 12 species are wild, 19 are cultivated and 4 are puschased. Dicots consist of 47 families, 112 genera and 143 species. Out of them 61 species are wild, 68 are cultivated and 14 are purchased.

\section{Medico-ethnobilogy}

Balmi has the profound indigenous knowledge to cure various diseases. While using the medicine, local healer, the Jhankri enchants mantras. This seems quite an unusual in comparison to the modern allopathic medicine systems. There are 12 orders and 13 families of animals which include 15 genera and 15 species. Among them 13 are wild and 2 are domesticated. They use the fats, sting, total animal body, blood, web, meat, bile juice, head and the mud where the animal live, and the eggs of animals for the medicinal purposes.

Table 1. Animals of Medicinal Importance to the Balami

\begin{tabular}{|c|l|l|l|l|l|l|}
\hline $\begin{array}{r}\text { S. } \\
\text { N. }\end{array}$ & Diseases & Order & Family & Animal Species/ & $\begin{array}{l}\text { Common/ } \\
\text { Local name }\end{array}$ & Animal parts \\
\hline 1. & Headache Rheumatism & Carnivora & Canidae & Canis aureus & Siyal & Meat \\
\hline 2. & Arthritis & Carnivora & Felidae & Felis chaus & Habsilo & Meat \\
\hline 3. & Rheumatism (Bath rog) & Carnivora & Felidae & Selenarctos thibetanus & Bhalu & Fats and bile \\
\hline 4. & Asthma & Rodentia & Hystricidae & Hystrix brachyura & porcupine & Bile juice \\
\hline 5. & Dysentery & Galliformes & Phasinidae & Gallus gallus domesticus & Kukhura & Egg \\
\hline 6. & Infertility & Passeriformes & Ploceidae & Passer domesticus & Vangera & Blood \\
\hline 7. & Asthma & Stringiformes & Stringidae & Bubo bubo & Huchil & Head \\
\hline 8. & Leprocy & Squamata & Gekkonidae & Hemidactylus flaviviridis & Mausuli & Body \\
\hline 9. & $\begin{array}{l}\text { Pneumonia, Typhoid, Small } \\
\text { wounds }\end{array}$ & Anura & Bufonidae & Bufo malanosticus & Toad & $\begin{array}{l}\text { Legs and eggs } \\
\text { with water }\end{array}$ \\
\hline 10. & Weakeness in animals & Pectinibranchia & Pilidae & Pila sp. & sankhekira & Body \\
\hline 11. & Backpain and bone fracture & Stylomnatophora & Helicidae & Helix sp. & Chiplikira & Whole part \\
\hline 12. & Head fracture & Arania & Araneae & Araneae sp. & spider & Web \\
\hline 13. & $\begin{array}{l}\text { Paralysis and various } \\
\text { diseases of nervous system }\end{array}$ & Hymenoptera & Vespidae & Plytis stigma & wasp & Sting \\
\hline 14. & Cough & Isoptera & Termitidae & Termite sp. & Dhamira & Mud \\
\hline 15. & Neural disease & Hymenoptera & Vespidae & Vespa sp. & & Sting and saliva \\
\hline
\end{tabular}

Balami has great faith upon the healing property of wild herbs, medicinal plants and advice of tribal healers. They don't visit the nearest health post for the treatment of simple diseases like cuts, wounds, diarrhoea, cold, asthma etc. They use 45 different species of plants for the medicinal purpose. Among them 32 are wild, 12 are cultivated and 1 is purchased. All these medicinal plants can be catagorised under 36 families and 44 different genera. They use the leaf, fruit, bark, stem, total shoot, seed, rhizome and flowers of the plant for the medicinal 
purposes. The animals and plants used for particular disease with their parts and administration have been given in the table below.

Table 2. Plant species of Medicinal Importance to the Balami

\begin{tabular}{|c|c|c|c|c|c|}
\hline S. N. & Families & Plant Species & \begin{tabular}{|l|} 
Common Local \\
Name
\end{tabular} & Parts Used & Diseases/ Problems \\
\hline 1. & Acanthaceae & Justicia adhatoda Linn. & Asuro & leaf & Bronchitis/ Dendruff \\
\hline 2. & Amaranthaceae & Achyranthes bidentata & Datiwan & Stem & Fever and toothache. \\
\hline 3. & Amaryllidaceae & Allium hyposistum (Sternan) & Jimbu & Leaf & Cough and cold \\
\hline 4. & Araceae & Acoras calamus $\mathrm{L}$. & Bojho & Rhizome & Cough and Bronchitis \\
\hline 5. & Berberidaceae & Berberis asiaticaa Dc. & Chutro & Fruit & Skin disease, Diarrhoea \& Jaundice \\
\hline 6. & Boraginaceae & Cynoglossum lanceolatum Forsk & Kuro & Entire plant & Mumps and cuts \\
\hline 7. & Betulaceae & Betula alnoides Buch-Ham. ex.D.Don & Saur & Bark & Excessive mensuration \\
\hline 8. & Capparaceae & Crataeva unilocularis Buch. Ham, & Siplican & $\begin{array}{l}\text { Seed/ } \\
\text { Bark/ leaf }\end{array}$ & $\begin{array}{l}\text { Disorder of urinary organ/ Loss of } \\
\text { apetite }\end{array}$ \\
\hline \multirow[t]{2}{*}{9.} & Combretaceae & $\begin{array}{l}\text { Terminalia bellirica (Gaertn) } \\
\text { Roxb. }\end{array}$ & Barro & Seed & $\begin{array}{l}\text { Anemia, Ulsers, cough, fever, skin } \\
\text { diseases }\end{array}$ \\
\hline & & Terminalia chebula Retz. & Harro & Seed & $\begin{array}{l}\text { Dysentry, Diarrhoea, ulsers, } \\
\text { wounds, jaundice, cough, } \\
\text { neuropathy, blood pressure. }\end{array}$ \\
\hline \multirow[t]{3}{*}{10.} & Compositae & Artemisia vulgaris L. & Titepati & Shoot & Cough, asthma, cuts, wounds \& scabies. \\
\hline & & Eupatorium adenophorum Spreng & Banmara & Leaf & Cuts and Wounds \\
\hline & & Helianthus annus L. & Surya mukhi & Leaf/seed & Ulcers and wounds burnt skin. \\
\hline 11. & Convolvulaceae & Cuscuta reflexa $\mathrm{Pl}$. & Akasbeli & Stem & Jaundice, asthma, diarrhoea \\
\hline 12. & Cucurbitaceae & Melothria heterophyla (Lour) & Bankakra & Fruit & Neck ache and Fever \\
\hline 13. & Nephrolepidaceae & Nephrolepis auriculata (L) & Paniamala & Fruit & $\begin{array}{l}\text { Indigestion, fever, Uteritis in } \\
\text { buffalo }\end{array}$ \\
\hline 14 & Dryopteridaceae & Tectaria coadunata (Wall ex) & Kalo niuro & W. Plant & Diarrhoea and dysentry \\
\hline \multirow[t]{2}{*}{15.} & Ericaceae & Gaultheria fragrantissima Wall & Dhasingare & Fruit & $\begin{array}{l}\text { Rheumatism and against hook } \\
\text { worms }\end{array}$ \\
\hline & & Rhododendron arborium Smith. & Laliguras & Flower & Blood dysentry, diarrhoea. \\
\hline 16. & Euphorbiaceae & Phyllanthus emblica Linn. & Amala & Fruit & $\begin{array}{l}\text { Haemorrhage, diarrhoea and } \\
\text { dysentry }\end{array}$ \\
\hline 17. & Gramineae & Cynodan dactylon Linn. Pers & Seto dubo & Leaves & Cuts and wounds, epilepsy \\
\hline 18. & Hyperaicaceae & Hypericum uralum Buch-Ham. & Khareto & Leaves, Stem & Cut \\
\hline \multirow[t]{2}{*}{19.} & Labiatae & $\begin{array}{l}\text { Pogostemon bengalensis (Burm. } \\
\text { f.) Kuntze }\end{array}$ & Rudilo & Shoot/root & $\begin{array}{l}\text { Cough sinusitis, diarrhoea and } \\
\text { vomiting. }\end{array}$ \\
\hline & & Ocimum sanctum $\mathrm{L}$. & Tulasi & Shoot/Seed & Bronchial infection and fever \\
\hline 20. & Lauraceae & Lindera neesiana (Nees) Kurz. & Siltimur & seed & Diarrhoea, Abdominal pain \& fever \\
\hline \multirow[t]{3}{*}{21.} & Leguminosae & Abrus precatorius L. & Ratigedi & Fruit & Itching of eye \\
\hline & & Cassia fistula L. & Raj briksha & Seed & $\begin{array}{l}\text { Snake bite, rheumatism, Diarrhoea } \\
\text { and inflammation }\end{array}$ \\
\hline & & Mimosa pudica L. & Lazawati & shoot & $\begin{array}{l}\text { Bite of the scorpion sting, } \\
\text { Rheumatism }\end{array}$ \\
\hline 22. & Liliaceae & Aloe barbadensis Mill. & Gheeukumari & Leaves & Intestinal worms \\
\hline \multirow[t]{2}{*}{23.} & Meliaceae & Azadirachata indica (Juss) & Neem tree & Leaf & Blisters and Allergy \\
\hline & & Toona ciliata Roxb.ex Rotti \& Willd & Tuni & Bark & Dysentery, cough, Bronchitis \\
\hline 24. & Myrtaceae & Pisidium guajava Linn. & Amba & Fruit/Leaf & High blood pressure, Bleeding gum \\
\hline 25. & Oleaceae & Nyctanthes arbor-tristis (L) & Paarijaat & Flower & Blisters and wound in the neck \\
\hline 26. & Orchidaceae & Dactylorhiza hatagirea (D. Don) & Paanch aunle & Tubers & $\begin{array}{l}\text { Diabetes, Dysentery, Diarrhoea, } \\
\text { Seminal weakness. }\end{array}$ \\
\hline
\end{tabular}




\begin{tabular}{|c|c|c|c|c|c|}
\hline 27. & Punicaceae & Punica gromatum L. & Anar & Fruit & Low blood pressure. \\
\hline 28. & Rhamnaceae & Zizyphus mauritiana Lam. & Bayer & Root & Measles and boils \\
\hline 29. & Rosaceae & Pyrus pashia Buch- Ham & Mayal & Fruit & $\begin{array}{l}\text { Wounds, eye strain, excessive } \\
\text { menstrual cycle }\end{array}$ \\
\hline 30. & Rutaceae & Zanthoxylum armatum (D.C.) & Timur & Fruit/leaves & Skin diseases and ring worms \\
\hline 31. & Solanaceae & Solanum xanthocarpum Schard. & Kantakari & Fruit & Toothache, sore throat. \\
\hline 32. & Theaceae & Schima wallichii (DC.) Korth. & Chilaune & Bark & Taeniasis \\
\hline \multirow[t]{2}{*}{33.} & Umbelliferae & Cantella asiatica $\mathrm{L}$. & Ghodtapre & Leaves & Fever, Uric acid \\
\hline & & Foeniculum vulgare (Mill) & Madhesi Sunmps & Seed/Shoot & Chest, kidney and spleen trouble \\
\hline 34. & Urticaceae & Utrica dioica $\mathrm{L}$. & Sisnu & Shoot/Root & Fracture, Jaundice and toothache \\
\hline 35. & Verbenaceae & Vitex negundo L. & Simali & Shoot/Flower & Headache, Sinusitis (pinash) \\
\hline 36. & Zingiberaceae & Hedychium ellipticum (Buch-Ham) & Ban Besar & Rhizome & Fever \\
\hline
\end{tabular}

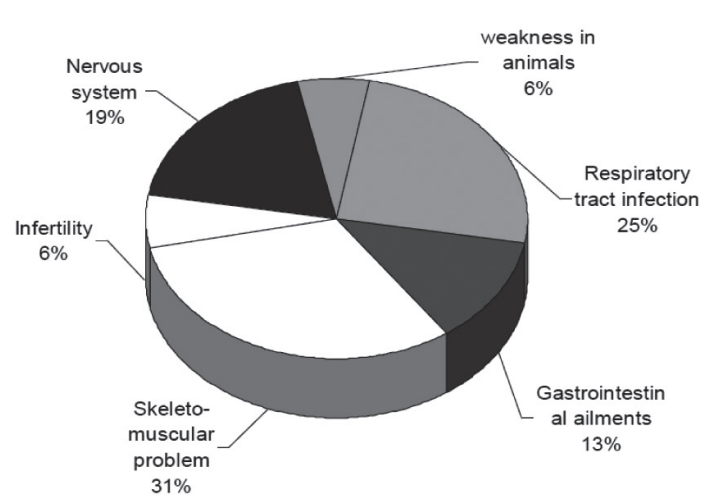

Fig. 4. Major disease categories and associated animal species

\section{Indigenous knowledge}

The kind of knowledge which is inherited from one generation to another generation is called indigenous knowledge. The Balami were woodcutter and seller spending the semi-nomadic life at the periphery of the valley. Still some groups cut and sell the woods to the city. More than this they are good field workers. They have good knowledge in making plough. Women make mats out of straw. They have good knowledge of making wine (jand) and alcohol (raksi). Some of the Balami people are busy at making houses and carpentry. They are famous in the periphery as the collector of old buffaloes and goats and sell them in the butcher shops in the valley. One of the interesting things about Balami is that they should rare oxen and plough the field which can be taken as one of the indigenous knowledge.

\section{DISCUSSION}

Balami are very much resourceful in terms of ethnobiological knowledge. Though they occupy a comparatively small geographic range, they use wide variety of floral and faunal species. The present study documents 65 different kinds of animal species both wild and domestiocated and 185 different plant species, both wild and cultivated for different utilities. Comparatively

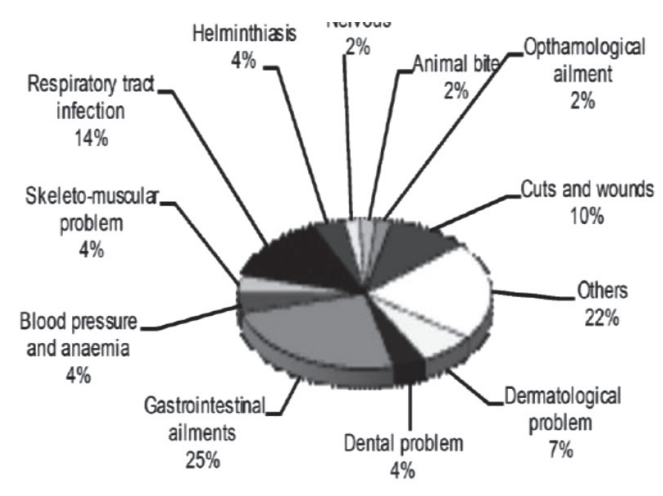

Fig. 5. Major disease categories and associated plant species

354 plants species and 127 animal species were used by Chepangs of Makawanpur district (Manandhar, 2000). The Danuwars of Peple VDC of Chitwan used 48 animal species and 224 plant species (Pathak, 2000). Bankariya of Makawanpur district used 58 species of animals both wild and domesticated, 268 different species of plants both wild and cultivated (Pokhrel, 2006). Magars of Salija VDC of Parbat district used 85 species of plants and 18 species of animals for medicinal purposes (Thapa, 2008).

The health care system of Balami was found to make extensive use of plants and animal products. The treatment of ailments with remedies made from animals and their products is known as zootherapy (Alves \& Rosa, 2005). Since ancient times, zootherapy has been integral to the traditional pharmacopoeias of many cultures (Mahawar and Jaroli, 2007). And has comprised a fundamental element to well known traditional medicinal systems, such as Ayurvedic medicine, Traditional Chinese medicine and ancient Egyptian medicine. Records of the medicinal use of animals and their byproducts date back to the invention of writing. Balami make use of 12 orders and 13 families of animals which include 15 genera and 15 species for the treatment of various diseases. Among them 13 are wild and 2 are domesticated. They 
use fats, sting, total animal body, blood, web, meat, bile juice, head, mud where the animal live, and eggs of animals for the medicinal purposes. 32 species out of 127 animal species used by Chepangs of Makawanpur have medicinal value (Manandhar, 2000). Among the 58 animal species 8 species are considered to be of medicinal utility in treatment of 7 diseases or ailments by Bankariya (Pokhrel, 2006). 18 animal species were used for of 21 different ailments by Magars of Salija VDC of Parbat district (Thapa, 2008).

Medicoethnobotanical study of Balami reveals that they utilize most of the plant species found in their locality. They use 45 different species of plants for the medicinal purpose. Among them 32 are wild, 12 are cultivated and 1 is purchased. All these medicinal plants can be catagorised under 36 families and 44 different genera. They use the leaf, fruit, bark, stem, total shoot, seed, rhizome and flowers of the plant for the medicinal purpose. 59 species of plants were listed for the Chepangs of Makawanpur district among 121 (Manandhar, 2000). People of Padampur used 130 medicianl plants (Rijal, 1994). Danuwars of Deuvumi of Baluwa VDC of Kavrepalanchock used 37 species out of 218 species of plants for medicinal purposes (Ghemire, 2000). Out of 227 plant species Gurungs of Waling Municipality of Syangja used 39 species of plants as medicianal value (Pangeni, 2005). Bankariya were found to use 82 plant species to cure more than 35 different diseases (Pokhrel, 2006). Magars of Salija VDC of Parbat district used 85 species of medicinal plants for the treatment of various diseases (Thapa, 2008).

The Balami use animal products to cure diseases like headache, arthritis, asthma, dysentery, infertility, cough, paralysis, Typhoid etc. The animal species used by Balami having medicianal utility are also supported by the findings of other researchers. For example; the cooked meat of Canis aureus was used for the treatment of rheumatism in the present research was also reported by Kaundinya (1998), Acharya (1999), Dhakal (2004), Koirala (2004), Pangeni (2005), Pokhrel (2006) and Thapa (2008). Hystrix brachyuran (porcupine) is used for the treatment of Asthma similar to the study conducted by Kaundinya (1998), Acharya (1999), Tamang (2003), Dhakal (2004), Pangeni (2005) and Thapa (2008). Helix species (Chiplikira) in the the present research is used for the backpain and the bone fracture which was similar to the study conducted by Pangeni (2005), Ghimire (2000) and Thapa (2008). Cooked meat of Felis chaus (habsilo) is used for arthritis in the present study. Pokhrel (2006) also reported for the same use. In the present finding Arnea species is mixed with bitten rice and red mud to cover the factured part of bones. Pokhrel (2006) reported the same species used by Bankariya for the treatment of bone fracture in case of fowl and Pangeni (2005), reported for the treatment of corneal ulser. In the present study the bile of Selenarctos thibetanus (Bhalu) was used for rheumatism. But, the other species Melursus ursinus was used for unconciousness in the finding of Pokhrel (2006).

Similarly, Balami use plant parts and plant extracts to cure the diseases like allergy, cut, wound, cough, jaundice, anaemia, asthma, rheumatism, diarrhoea, mumps, fracture, urinary disorder, taeniasis, scabies etc. The medicinal plant species reported to have folk medicinal utility by Balami in the present study are also supported by the findings of the other researchers. For example; the juice of the Justicia adhatoda (asuro) was found to be used in the treatment of bronchitis in the present study. Thapa (1998) also reported similar uses in his study. Thapa (2008) has reported the use of the same plant decoction with hot ash fire for the treatment of sinusitis. Stem of Achyranthes bidentata (Datiwan) infusion is used for fever in the present study. Pangeni (2005) and Thapa (2008) reported for the same purpose with inappetence due to evil eyes (Bigar Pareko). But, Thapa (1998) has reported its infusion for the treatment of fever and Ghimire (2000) has reported its root will be rubbed in waist or head if placenta of baby does not come. Acoras calamus (Bojho), its rhizome is used for cough and bronchitis in the present study. Thapa (1998) and Pangeni (2005) reported for the same purpose. But, Ghimire (2000) reported for sore throat, Pokhrel (2006) reported for sore throat and bronchial catarrh. Thapa (2008) reported the use of same plant species for cough and cold. Berberis asiaticaa (chutro) in the present study was found to be used in skin disease, diarrhea and jaundice whereas Thapa (2008) reported for eye boils. Eupatorium adenophorum (Banmara) is used for cuts and wounds. Thapa (1998) reported for the same purpose. Ghimire (2000) reported for lung cancer, Pokhrel (2006) for cut, wound, cough and cold and Thapa (2008) reported the use of same plant species for cut and wound.

\section{CONCLUSION}

Balami, mediators between the villages and towns are resourceful in ethnobiology, indigenous knowledge and ethnomedical practice. Ethnomedicine is one of the important systems of primary health care in this community. At present the use of plant and animal products are sustainable in terms of environment. However, poor sanitation, soil erosion, ignorance are the problems of the community. Immediate actions are to be implemented for the diversified utilization of plant and animal species. For the conservation of the ecology and their indigenous knowledge about ehnomedical biology, the following recommendations are made:

- Conservation of their indigenous knowledge systems along with the use of medicinal plants and animals, providing guidelines for sustainable development, documentation, chemical research and feeling of ownership are required.

- Public awareness about the proper sanitation, 
modern agriculture, education, social evils like alcoholism and smoking should be launched.

- Mitigation measures should be implemented for the damage caused by the landfill site. Foul smelling, leachate disposal, pollution and environment degradation should be immediately controlled for the conservation of natural flora and fauna.

- Traditional healers should be motivated to inherit their knowledge.

\section{ACKNOWLEDHEMENTS}

Sincere thanks goes to Central Department of Zoology, T.U., Kirtipur. We are particularly thankful to the local healers Santabir Balami and Mankaji Balami. We are indebted to Dhanamaya Ballami, Indrajit Balami, Sukale Balami, Ramsaran Balami, Heera Balami, Sanu Balami, Laxman Balami, Gopal Balami, Sanukanchha Balami, Ram Maharjan, Anil Maharjan, Rajesh Goit. Enormous thanks to grandfather, Ramprasad Ghimire and cousin, Prakesh Ghimire for their constant cooperation during the field visit.

\section{REFERENCES}

Alves, R.R.N. and Rosa, I.L. 2005. Why to study the use of animal products in traditional medicine? Journal of Ethnobiology 107 (2): 259-276.

Baral, S.R. and Kurmi, P.P. 2006. A compendium of Medicinal Plants in Nepal. Mass Printing Press, Chhauni, Kathmandu, Nepal.

CBS. 2001. Population Census. Central Bureau of Statistics, Kathmandu, Nepal.

CBS. 2012. National population and housing census 2011 (National Report). Kathmandu, Nepal.

Dhakal, B. (2000). Study on Ethnobiology of the Kumals: A case study of Taranagar VDC of Gorkha. $M$. Sc. Thesis, Central Department of Zoology, T.U., Kirtipur, Kathmandu, Nepal.

DNPWC. 2009. Annual Report 2065/66, 2008/2009. Department of National Parks and Wildlife Conservation, Ministry of Forest and Soil Conservation, Government of Nepal, Kathmandu.

Ghimire, V. 2000. Study on the ethnobiology of the Danuwars (A case study of Deuvumi Baluwa V.D.C. of Kavrepalanchok). A dissertation submitted to the Central Department of Zoology, Kirtipur, Kathmandu, Nepal.

Gary P.N. 2010. Perspectives in ethnobiology, ethnophenology and climate change. Journal of Ethnobiology vol. 30

IUCN. 2009. Water and Wetlands. Are we running out of water? http://iucn.org.

Kaundinya, D.P. (1998). Ethnobiology of the Kumals: A case study of Chirtungdhara VDC of Palpa District. A dissertation submitted to the Central Department of Zoology, Kirtipur, Kathmandu, Nepal.
Koirala, A. 2004. Ethnobiology of Musahars: A case study of Bachhauli VDC of Chitwan District. M.Sc. Thesis. Central Department of Zoology, T.U. Kirtipur, Kathmandu, Nepal.

Koirala, S. 2004. Ethnobiology of the Satars: A case study of Korubari VDC of Chitwan District. M.Sc. Thesis. Central Department of zoology, T.U. Kirtipur, Kathmandu, Nepal.

Mahawar, M. and Jaroli, D.P. 2007. Traditional knowledge on zootherapeutic uses by the saharia tribe of Rajsthan, India. Journal of Ethnobiology and Ethnomedicine, 3 (1):25.

Manandhar, B.P. 2000. Ethnobiology of the Chepangs: A case study of Makwanpur District. M.Sc. Thesis. Central Department of Zoology, T.U. Kirtipur, Kathmandu, Nepal.

Pangeni, N. P. 2005. Ethnobiology of the Gurungs (A case study of Waling Mincipality of Syangja district). A dissertation submitted to the Central Department of Zoology, Kirtipur, Kathmandu, Nepal.

Pokhrel, B.M. 2006. Ethnobiology of a Vanishing Indigenous Group: The Bankariya. A dissertation submitted to the Central Department of Environment Science, Kirtipur, Kathmandu, Nepal.

Shrestha, J. 1981. Fishes of Nepal. Tribhuvan University Curriculum Development Centre, Kathmandu Nepal.

Shrestha, T.K. 2003. Wildlife of Nepal, $2^{\text {nd }}$ Ed. Bimala Shrestha, Kathmandu, Nepal.

Singh, N.B. 1997. The Endangered Raute Tribe:Ethnobiology and Biodiversity, Gloreca Ethnobiology, Kathmandu, Nepal.

Thapa, C.B. 1998. Traditional uses of plants and their distribution in Shivapuri watershed and wildlife reserve area. A dissertation submitted to the Central Department of Botany, Kirtipur, Kathmandu, Nepal.

Thapa, S. 2008. Medico-ethnobiological knowledge of the Magars: A case study of Salija VDC, Parbat

District, Central Nepal. M.Sc. Thesis. Central Department of Environmental Science, T.U. Kirtipur, Kathmandu, Nepal.

Tilman D. 2000. Causes, Consequences and Ethics of Biodiversity. Nature 405: 208-211.

Toffin, G. (2007). Newar Society City, Village and Periphery. Himal Books. Patan Dhoka, Lalitpur, Nepal.

Upadhya, R. 2005. Ethnobiology of the Meches (A case study of Jalthal V.D.C. of Jhapa District. A dissertation submitted to the Central Department of Zoology, Kirtipur, Kathmandu, Nepal.

Upadhaya, T. 1999. Ethnobiology of the Botes (Majhi): A case study of Chhamdighat, Bamgha and Jujang VDCs of Gulmi District. A dissertation submitted to the Central Department of Zoology, Kirtipur, Kathmandu, Nepal. 